\title{
The works of Shihab ad-din al-Marjani on Islamic scholastic theology
}

\section{D.A. Shagaviev}

Russian Islamic Institute, Kazan, the Russian Federation

Bolgar Islamic Academy, Bolgar, the Russian Federation

Tatarstan Academy of Sciences, Kazan, the Russian Federation

ORCID: https://orcid.org/0000-0003-2769-8333,e-mail: saiddamir@mail.ru

\begin{abstract}
The well-known Tatar historian and theologian Shihab al-Din al-Marjani (18181889), who worked as an imam and teacher of religious disciplines in Kazan, left behind more than 30 scientific and didactic written works. Some of his works were published in Kazan, Istanbul and Cairo. The subjects of the treatises of Marjani touch upon the Islamic faith, law, ethics, Quranic sciences and the history of Islam and Muslim peoples.

The most important contribution to Islamic science is his books on Islamic scholastic theology and Sunni dogma. There are seven works on the abovementioned topics from Shihabuddin Marjani’s heritage on Islamic sciences: "al-Hikma al-baligha”, "al-'Adhb al-furat", "al-Mathal al-a'la”, "Haqq al-bayan”, “at-Tariqa al-muthla”, "Haqq al-'aqida” and "Sharh mukaddimat ar-risalya al-shamsiyya”.

This article provides an overview of these works, gives a brief description of them, discusses the prints. It also sheds the light on their issues and points out the inaccessibility of some of them to researchers. Particular attention is paid to the work "al-Hikma al-baligha" ("Mature Wisdom"), which is a commentary on the well-known text in Sunni world, al-'Aqida al-nasafiyya.

The study uses descriptive and historical scientific methods with elements of theological analysis. Accessible sources in Arabic were directly investigated, and the works of contemporaries of the Tatar scholar were also used.
\end{abstract}

Keywords: Shihab al-Din al-Marjani; Islam; scholastic theology; kalam; 'aqida; dogma; alHikma al-baligha; al-'Adhb al-furat

For citation: Shagaviev D.A. The works of Shihab ad-din al-Marjani on Islamic scholastic theology. Minbar. Islamic Studies. 2020;13(1):103-116. DOI: 10.31162/2618-9569-2020-131-103-116

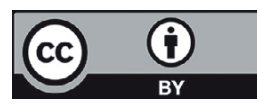

Контент доступен под лицензией Creative Commons

Attribution 4.0 License.

This work is licensed under a Creative Commons Attribution

4.0 License.

(C) D.A. Shagaviev 


\title{
Труды Шихабуддина Марджани по исламскому схоластическому богословию
}

\author{
Д.А. Шагавиев \\ Российский исламский институт, г. Казань, Российская Федеращия \\ Болгарская исламская академия, г. Болгар, Российская Федерация \\ Академия наук Республики Татарстан, г. Казанъ, Российская Федерация \\ ORCID: https://orcid.org/0000-0003-2769-8333, e-mail: saiddamir@mail.ru
}

Резюме: Известный татарский историк и богослов Шихабуддин Марджани (1818-1889), имам и преподаватель религиозных дисциплин в Казани, оставил после себя более 30 научных и назидательных письменных трудов. Некоторые из них были напечатаны в Казани, Стамбуле и Каире. Тематика трактатов Марджани затрагивает исламское вероучение, право, этику, коранические науки, историю ислама и мусульманских народов.

Наиболее важным вкладом в исламские науки являются его книги по исламскому схоластическому богословию и суннитской догматике. Из наследия Шихабуддина Марджани по исламским наукам мы обнаружили семь трудов, посвященных вышеуказанной тематике: «ал-Хикма аль-балига», «аль-“Азб аль-Фурат», «аль-Масаль аль-а“ля», «Хакк аль-байан», «ат-Тарика аль-мусля», «Хакк аль-‘акыда» и «Шарх мукаддимат ар-рисаля аш-шамсиййа».

В статье делается обзор данных трудов: дается краткая характеристика, говорится об их печатных изданиях, проливается свет на их проблематику, указывается на недоступность некоторых из них для исследования. Особое внимание уделяется труду «альХикма аль-балига» («Зрелая мудрость»), который является комментарием к известному в суннитском мире тексту «аль-'Акыда ан-насафиййа».

В исследовании использованы описательный и исторический научные методы с элементами теологического анализа. Непосредственно исследовались доступные оригинальные источники на арабском языке, также были использованы труды современников татарского ученого.

Ключевые слова: Шихабуддин Марджани; ислам; схоластическое богословие; калам; 'акыда; вероучение; аль-Хикма аль-балига; аль-'Азб аль-фурат

Для цитирования: Шагавиев Д.А. Труды Шихабуддина Марджани по исламскому схоластическому богословию. Minbar. Islamic Studies. 2020;13(1):103-116. (In Engl.) DOI: 10.31162/2618-9569-2020-13-1-103-116 


\section{Introduction}

Shihab al-Din ("Meteor of religion" or "Flying star of Islam") al-Marjani (1818-1889) or Abu-l-Hasan Harun ibn Baha’ al-Din al-Qazani al-Bulghari, also known in Russian documents and literature as Shagabutdin Bagautdinov or Shigabutdin Mardzhani, is a famous Tatar Muslim scholar from Kazan. He was born in a village of Yabinchi (Yepanchino) of Kazan province (today Tatarstan), but the roots of his family trace to a neighboring village of Maryan (Marjan in Arabic) [1, p.177; 2, p.22]. Young Marjani, having good initial knowledge of Islamic Sharia and the Arabic language from the local madrassah teachers, in 1838 went to Bukhara and Samarkand. After returning from Central Asia, where Marjani studied for 11 years, he began composing his historical and theological works. Eventually, he became an obsessed Islamic scholar in Russia, who was even known abroad through his writings on history and Islamic sciences.

Marjani himself in his autobiography, in the second volume of "Mustafad al-akhbar" listed his 28 published and handwritten works, also mentioning his sermons (khutab), prayers (ad'iya) and letters (al-makatib) [3, p. 52-53]. Not all the works were included in the list, because by the time of writing "Mustafad alakhbar" some of them have not been completed yet. Rizaetdin Fahretdinov (Ridha al-Din ibn Fakhr al-Din) in his "Athar" mentioned only 11 published and three manuscript works of Marjani he knew about [1, p.182]. In a collection "Marjani” of 1915 Alimjan Barudi listed all in all already 27 works [4, p. 367-369]. Finally, the modern researcher Munir Yusupov mentions 33 works [2, p. 257-259]. ${ }^{1}$ All of Marjani's works are written in Arabic, except for several books in Tatar. About half of the works are devoted to Sharia subjects, the rest to history, literature and language. In total, according to our information, Sh. Marjani wrote 19 theological works except for little-known small size papers. Seven works are devoted to Islamic scholastic theology ${ }^{2}$. While some of the works by Marjani on Islamic law are published even in modern Islamic world, however, this, unfortunately, cannot be said about the works on Islamic creed. Continuing the research we will give a short

\footnotetext{
1 Unfortunately, in the lists of domestic researchers a Cyrillic transliteration of the Arabic titles of Marjani's works is often distorted. In this study, we tried to eliminate such shortcomings.

${ }_{2}$ It should be noted that sometimes Marjani discusses theological issues in his historical works, for example, in the book "Wafiyyat al-aslaf" [5, P. 273-274]. In addition, we noted that in the book «Nazurat al-haqq», which is highly devoted to the issues of Fiqh, the author also discusses the status of the science of Kalam and the main provisions of the Ușul al-Din (Islamic dogma).
} 
overview of these works and pay attention to their subject, especially regarding the first work. All of them are presented in Arabic.

\section{Al-Hikma al-baligha \{الحكمة البالغة الجنية في شرح العقائد الحنفية}

The first work in terms of importance is the book "al-Hikma al-baligha al-janiyya fi sharh al-'aqaid al-hanafiyya [or al-nasafiyya]" ("Extremely mature wisdom in the interpretation of the Hanafi [or the Nasafi] dogmas"1). ${ }^{2}$ It was published in Kazan in 1889 (168 pages) [9] ${ }^{3}$. This work is an interpretation of the Symbol of the Faith of Imam Abu-Hafṣ al-Nasafi (461-537/1068-1142), so alZirikli refers to this book under a simpler title "Sharh 'aqaid al-Nasafi" [11, p. 258]. 'Alimjan Barudi in his list of Marjani's works giving the title changes the word "al-hanafiyya" to "al-nasafiyya", which is likely to be a clarification [4, p. 367]. The author probably chose the term "al-hanafiyya" to emphasize the origins of the Nasafi creed.

A very short treatise on the Hanafi doctrine of views, known as "al-'Aqaid al-Nasafiyya" ("Nasafi creed") 4 , plays a decisive role in the spread of the Maturidi school of Sunni Kalam [12, p. 197]. The Hanafites mostly belong to this school of Islamic Theology. According to Turkish researchers, fame "Nasafi creed" became so famous in a Muslim world through the interpretation of al-Taftazani (died in 797/1395) 5 "Sharh al-‘aqaid" [13, p. 61]. As Dzhamaletdin Validi (Jamal al-Din al-Walidi) wrote, "the most popular works in Muslim, including Tatar, madrassas were 'Aqaid Nesefi with commentary by Taftazani” [14, p. 19; 7, p. 105].

Apparently based on the fact that the title contains the phrase "sharh al"aqaid" ("Commentary on the doctrine of views"), some researchers concluded that

\footnotetext{
${ }^{1}$ Munir Yusupov translated it as: «A mature philosophy that helps to explain the faith of Hanifites» [2, P. 258]. Aydar Yuzeev translates it as «A book about mature philosophy that helps to explain the doctrines of the Hanafites» [6, P. 35]. The same is translated by Rezeda Safiullina as «A book of mature wisdom on commenting on the Dogmas of Hanefites» [7, P. 106]. These three researchers gave a distorted transcription of the title (especially the third word), although the translation of the title was not affected. Our version of transcription, rewritten in Latin according to the Western system of transcription, coincides with the version of the German researcher Michael Kemper [8, p. 445, 487].

2 We put this work first because Marjani himself put it first on the list. So did Barudi. From the point of view of the content and theme of the book, it really deserves the position of the most important of Marjani's works. The creed or science of monotheism is the most important branch of Islamic knowledge, as a person's faith depends on understanding its aspects.

${ }^{3}$ There is a stereotypical republication of this book [10].

${ }^{4}$ Also known among Kalam scholars as «'Aqaid al-Nasafi» («Credo of al-Nasafi) or «Matn al-'Aqaid» («Text of the doctrine of views»).

${ }^{5}$ The sources give different dates of his death.
} 
this work by Sh. Marjani is a commentary to al-Taftazani's commentary [15, p. 60]. Undoubtedly, Sh. Marjani based his work on al-Taftazani's work, although he is mentioned there by name only three times [9, p. 70, 104, 159]. However, "al-Hikma al-baligha" is a commentary directly to the text of the credo of Imam al-Nasafi.

Shihabuddin Marjani had a negative opinion about al-Taftazani and his commentaries, which was the reason for writing his interpretation. Through the influence of Abu-1-Nașr al-Qurșawi (Gabdennasyr Kursavi), whose commentary on the al-Nasafi creed was scrutinized by Shihabuddin Marjani, decided to correct the errors and misconceptions of medieval commentators [16, p. 44b, 45a]. Highprofile scandals related to disputes between Qurșawi and his opponents were still fresh in the memory of Marjani's contemporaries. Tatar ulamas virtually divided into two camps - supporters and opponents of Qurșawi. Gulnara Idiyatullina, a researcher of the theological heritage of Qurșawi, writes: "The book ["Sharh al-'aqaid al-nasafiyyah al-jadid" ("The new commentary to al-Nasafi's creed”) of Qurșawi] touched upon the issues related to the essence (Dhat) and attributes (Șifat) of God, in particular, one of the main points of disagreements between maturidit al-Nasafi and ash'arit al-Taftazani, which consisted in determining the number of essential divine attributes (Șifat dhatiyya) that are eight or seven. The Bukhara ulamas, in whose eyes "Sharh" al-Taftazani enjoyed unquestionable authority, considered both opinions acceptable. Qurșawi did not support any of them. He asserted, that the only way is to use the definitions relating to God provided by Quran” [17, p. 46]. According to his works we can conclude that Marjani displays the same position.

Decision to refuse the famous comment was a bold and audacious step, as al-Taftazani in the eyes of the most of Sunnis was considered to be an indisputable authority, whose opinions had never been discussed. In his book "Wafiyyat al-aslaf wa tahiyyat al-akhlaf" ("Details on the predecessors and greeting to the successors"), Marjani writes about al-Taftazani: "He fanatically fought against the truth, in every way sought to support ideas of Shafi'its and Ash'arits, was extremely intolerant to Hanafites and philosophers on issues as Fiqh branches and its methodology, scornfully treated them in issues of rational and traditional knowledge... He wrote books "Sharh al-'aqaid al-nasafiyya" and "al-Tawdih" ("Explanation"), but most part of his commentary is improper and not full as a commentary. His commentary 
is defamation and notes are a reproach and condemnation" [16, p. 44b, 45a; 18 , p. 34-35]. He then mentioned the philosopher and mutakallim al-Sayyid al-Jurjani (1340-1413) $)^{1}$ "who disclosed the false brilliance of al-Taftazani's thoughts" [16, p. 45a; 18, p. 35.] Such a review of al-Taftazani's writings, if wisely disseminated, could have serious consequences on al-Taftazani's authority among the Hanafites, especially among zealots of this branch. But, who of the later theology scholars could compare with al-Taftazani, whose star rose so high. ${ }^{2}$ As already noted, any criticism in his side, even constructive, was doomed to failure; moreover, the critic could expect adverse consequences.

In the introduction to "al-Hikma al-baligha" itself, Shihabuddin Marjani condemns some groups and their leaders without naming them, after mentioning that the pure meanings and ideas of the Hanafi creed were distorted and misinterpreted [9, p. 2-3]. It is likely that this means al-Taftazani and those who consider him an authority on views.

Interestingly, that Hajji Khalifa, listing commentaries to the treatise of alTaftazani, told about another critic of this treatise, 'Abd al-Latif ibn Abi-l-Fath al-Kirmani, who believed that some points of the commentary do not correspond to the Sunnis doctrine [19, p. 1145]. Thus, Sh. Marjani was not alone in his negative attitude to a well-known authoritative commentary, but he was the only who dared to write the most detailed alternative interpretation. Unfortunately, this work by Sh. Marjani in Arabic, so important to the followers of Hanafi beliefs, for a number of reasons remained unknown and did not spread in the Islamic world.

There are some manuscripts with the full text or fragments from "al-Hikma albaligha”, which are similar to the printed version kept in Kazan Federal University (KFU) library 3 . In the book itself, the author writes that he completed composing it in 1273 Hijri (1856/1857). That is, about seven years passed after returning from the Central Asia, and at this time he officially worked as an imam of the 1st Kazan

\footnotetext{
1 Al-Sayyid al-Sharif 'Ali ibn Muhammad al-Jurjani (740-816 h.d.) is a philosopher, theologian, commentator of the famous work «al-Mawaqif» of "Adhud al-Din al-Iji (died in 1355). He created many works on logic, 'Aqida, Fiqh and Hadith'.

${ }^{2}$ He became so famous that his name was used to call the most talented and intelligent students of the science of Ușul (methodology of Fiqh and religion). For example, the Cairo faqih and mufassir Jalal al-Din al-Mahalli, the teacher of Imam al-Suyuti, was called «Arabic Taftazani».

${ }^{3}$ Dep. Rare Books, Manusc., Sci. Libr., KFU, No. 2183 (dated 1864 by the scribe), 2983 (sine anno, but contains the part following the main text of «al-Hikma», so it is written approximately after 1879), 3565 (dated 1869 by the scribe).
} 
mosque and taught in madrassas, and that period he had the first troubles with a merchant Ibrahim Yunusov and some mullahs. The book publishing was financed by a merchant Muhammadjan ibn Minhaj al-Din al-Karimi under the permission of the Ministry of Education on July 11, 1888 [9, p. 166 ${ }^{1}$.

In the printed version, the text of al-Hikma has 147 pages. It strictly follows in the sequence of statements of al-Nasafi's creed. Almost every statement, sometimes even a word, has a commentary. There are some notes and explanations on the margins of the main text. The Marjani's commentary can be conventionally divided into seven chapters. The first chapter (pp. 4-17) is devoted to the essence of things and the ways to perceive it, and to some extent is a philosophical introduction. The second chapter (pp. 17-57) touches upon purely theological matters (about the creation of the world, attributes of God, His predestination, freedom of choice in the actions of people). The third chapter (pp. 57-69) tells about the afterlife. The fourth chapter (pp. 69-73) is devoted to the issue of human faith. In the fifth chapter (pp. 73-87) the author studies the issues related to the prophets and angels. The sixth chapter (pp. 87-123) is devoted to the issue of the Caliphate and the Imamate. Finally, in the seventh chapter (pp. 123-147) some particular issues of the religious doctrine and law are reviewed.

\section{Al-‘Adhb al-furat \{العذب الفرات والماء الزلال الناقع لغلة روام الإبراز لأسرار شرح الجلال\}}

Another fundamental work is the book "al-'Adhb al-furat wa-l-ma' alzulal al-naqi' li-ghullat ruwwam al-ibraz li-asrar sharh al-Jalal” ("Fresh and lively spring water to quench the thirst for those wishing to learn the secrets of Jalal's interpretation"). It was published in Istanbul in 1292/1875 [3, p. 52; 20 $]^{2}$ and in 1316/1899. ${ }^{3}$ The Saltykov-Shchedrin State public library (St. Petersburg) keeps the manuscript of this work. The manuscript contains 200 pages [2, p. 259; 24]. This work is a commentary on the work of the Iranian scholar-theologian Jalal al-

\footnotetext{
${ }^{1}$ In 2018, Kazan publishing house «Huzur» made a reprint edition of this book [10].

2 Barudi reports that this work was published for the second time in Istanbul with the help of the Iranians [4, p. 367]. Apparently, Marjani had good connections with Iranian merchants. It is interesting that in the same year (1292 H./1876 A.C.) the famous Muslim reformer Jamal al-Din al-Afghani, while in Egypt, wrote his explanations to the same commentary of Jalal al-Dawwani [21, p. 11, 15].

${ }^{3}$ This is the edition available for us. It consists of two parts, each of which contains almost 300 pages. But this is taking into account the fact that along with Marjani's explanations in the margins of the book there are also explanations of Husayn al-Khalkhali (d. 1605), and the interpretation of Jalal ad-din al-Dawwani is published with the interpretation of Isma'il al-Kalanbawi (1730-1790) [22; 23].
} 
Din Muhammad al-Dawwani "Sharh al-‘aqaid al-'adhudiyya"1, known among the Tatars as "Mullah Jalal" ("Mella Jalal"), which in turn is a commentary to the Symbol of the Faith "al-'Aqaid al-'adhudiyya”, written by ash'arit mutakallim "Adhud al-Din "Abd al-Rahman al-Iji (died in 1355). This essential book "Mullah Jalal” of ash'ari kalam was studied by Tatar shakirds (students), that is why Marjani explanations to it were relevant for its time. However, this book has never been published in Kazan.

\section{Al-Mathal al-a'la \{المثل الأعلى\}}

The third is the book "al-Mathal al-a"la" ("Ideal"). Unfortunately, this work is still unavailable. Barudi, like Marjani, mentioned this title on the list without a commentary. Arab philosophers used this term to call the Supreme. Therefore, we believe that this work was of a philosophical nature. We also found out that a disciple of Shihabuddin Marjani, Zaki al-Din al-Muslimi², referred to this book, or rather to the section on attributes (Șifat) from it. ${ }^{3}$

\section{Haqq al-bayan \{حق البيان وتصوير في مسألة حدوث عالم الأمر والتقدير\}}

The fourth is the book "Haqq al-bayan wa-tașwir fi mas'alat huduth 'alam al-amr wa-l-taqdir" ("Truthful explanation and description about the origin of the world of testament and predestination"). It was published in the appendix to "alBarq al-wamidh" (6 pages) [25, p. 65-71]. This short essay is devoted to the issue of the origin of the world or universe. It argues the validity of the statement that the world is something that emerged after nothing. Marjani argues that the rest of the allegations or denials about the creation of the Universe do not belong to the sphere of mandatory Sharia issues [4, p. 369]. This theme was continued by Marjani's disciple Muhammad-Najib al-Tuntari (Tyuntari) in his work "Hudusi 'alame i'tiqad jihatendan ber nazar" ("The origin of the Universe in a view of Islamic belief") [26].

\section{Al-Tariqa al-muthla \{الطريقة المثلى والعقيدة الحسنى\}}

The fifth is the book "al-Tariqa al-muthla wa-l-'aqida al-husna" ("Perfect way and the finest belief”). It was published in Kazan in 1890 (15 pages) [7, p. 105;

\footnotetext{
1 Muhammad ibn As'ad al-Siddiqi ad-Dawwani (1427-1512), scholar and philosopher, judge of the Iranian province of Faris, author of numerous works in Arabic and Persian.

2 As we found out, he was a disciple of Marjani in the Sufi sense.

3 His short treatises or letters are published in the appendices to «al-Hikma al-baligha» [9, p. 156-163].
} 
27]. It contains criticism of the use of only logic and Kalam in matters of Islamic doctrine. According to Barudi, this essay plays the role of a summary of Taftazani's book "Tahdhib al-mantiq wa-l-kalam" ("The improvement of Logic and Kalam") [4, p. 367]. The national library of KFU has a manuscript version of this work (38 pages), transcribed by Burhan al-Din al-Shabkawi, a student of Marjani, in $1275 / 1859$ [28]. There are two parts in this treatise. The first studies the sources of the science of inference (ma'arib 'ilm al-nazr), the second - the issues (of study) of the most important knowledge (matalib al-Fiqh al-akbar), i.e. the dogmas of faith. In the preface, the author states that his treatise contains what is confirmed in the creed, and what the speculation has led to and what the faithful Muslims can rely on.

\section{Haqq al-‘aqida ('Aqida mukhtașara) \{حق العقيدة (عقيدة مختصرة)}

The sixth is the book "Aqida mukhtașara” ("Brief symbol of the Faith"). Published in Cairo in 1910 in the collection "Majmu'at al-rasail "(Collection of treatises") (7 pages) [29]. ${ }^{1}$ This work was found in the libraries of Cairo. As we thought, it is a Marjani's symbol of the Faith, which follows immediately after the text of "al-Hikma al-baligha" under the title "Haqq al-'aqida"("The Truth of the creed”) [9, p. 147-150]. A German researcher, who referred to the Cairo edition, points out that "Aqida mukhtașara" is written in rhymed prose and does not contain the scope of philosophical issues [8, p. 444], with which, for example, the "Nasafi creed" begins. The text of this brief symbol of the Faith corresponds to the content of "Haqq al- 'aqida", as we have seen after comparing the two texts. ${ }^{2}$ Thus, the Tatar theologian continued the tradition of previous Islamic scholars, such as al-Tahawi, al-Nasafi, al-Iji, al-Sanusi and others, who created Sunni symbols of the Faith.

\section{Sharh muqaddimat al-risala al-shamsiyya شرح مقدمة الرسالة الشمسية\}}

The seventh is the book "Sharh muqaddimat al-risala al-shamsiyya fi-lmantiq" ("The Commentary to the preface of the treatise «Shamsiyya» on logic") (not published) [4, p. 368]. This is an explanation to the beginning of the famous book "Shamsiyya" of the philosopher and mathematician Najm al-Din al-Katibi

1 This work does not appear in any lists. It was mentioned by a German researcher M. Kemper [8, p. 444]. Munir Yusupov mentioned this work in the list of sources and literature, but he did not mention it in the bibliography of Marjani's works [2, p. 270].

${ }^{2}$ In 2013 we published an edition of the original text with a translation and a brief preface [30]. 
(1203-1277) of Qazvin (Iran). Since the methods of logic were used in Islamic theology (Kalam), we put this book in this section. This work is also still unavailable.

\section{Conclusion}

In this short study, we do not exclude the possibility that there are other works on scholastic theology. We did not include in this list Marjani's treatise "alHaqq al-mubin fi mahasin awda“ al-din" ("The Obvious Truth About the Merits of the Prescriptions of Islam”), which discusses the arguments of the Quran's miracles as confirmation of the truth of the prophetic mission of Muhammad (peace be upon him). This work is appropriate to consider as a work on Quranic studies, although it is indisputable that the issue under study is related to Islamic dogma.

It is also important to note that Shihab al-Din al-Marjani discussed some of the issues of Kalam in books on Islamic law and its methodology. For example, he considered the issue of the validity of the science of Kalam in the book "Nazurat alhaqq" ("Review of Truth"), and the issue of beauty and disgust in actions from the point of view of the reason (al-tahsin wa-l-taqbih al-'aqliyyan) in the book "Hizamat al-hawashi" ("Collection of Comments"). In the legal manuscript "Tadhkirat almunib" ("Reminder of the repentant"), the Tatar scholar examined the dogmatic teachings of Russian Orthodox Christians among the rest, mainly legal issues.

It should be added that the book "al-Barq al-wamidh" ("Brilliant Lightning"), mainly devoted to Islamic law, contains not only the composition "al-Barq alwamidh", but also 18 essays (taharir) [25, p. 131-132] of a various volume. There is the book "Haqq al-bayan" ("Truth of clarification"), which was mentioned under the fourth paragraph on our list. There are other five essays addressing certain subtle issues of Islamic dogma. For instance, there is a 3-page essay on the meaning of Islam and Sunnism (fi ma'na al-islam wa ahl as-sunna wa-l-jama'a) [25, p. 131] among these essays. These works need detailed and in-depth research.

Under Tsarist Russia conditions of that era, an extraordinary Islamic scholar appeared in Kazan, who was the author of books on 'Aqida, Fiqh, Quran history and Islam. Marjani has written seven works on Islamic theology and dogma. Moreover, two of them (No. 1, No. 2) are fundamental interpretations of well-known Sunni world sources. All these theological works except two (No. 3 and No. 7) were published and are available for researchers. Some of the books were even published outside Russia. There are also some works as Shihab al-Din Marjani that 
have been least studied because of their complex subject matter. Therefore, after the foundation of Bolgar Islamic Academy there appeared a hope that these works would be chosen as a theme for some in-depth research by postgraduate students.

\section{References}

1. Fakhretdinov R. Bolghar wa Qazan toreklere [Bulgar and Kazan Turks]. Kazan: Tatar Publishing House; 1993. 287 p. (In Tatar)

2. Yusupov M.H. Shigabutdin Mardzhani [Shihabuddin Marjani]. Kazan: Tatar book publ.; 2005. 271 p. (In Russian)

3. Shihab al-Din al-Marjani. Mustafad al-akhbar [Useful news]. Vol. 2. Kazan; 1900. 368 p. (In Old Tatar)

4. 'Alimjan al-Barudi. Marjani haqynda ijmaly malumat [Summary about Marjani]. Collection of Marjani. Kazan: Maarif; 1915, P. 360-378. (In Old Tatar)

5. Shihab al-Din al-Marjani. Muqaddimat kitab wafiyyat al-aslaf wa-tahiyyat al-akhlaf [Introduction to the book "Devotion to predecessors and greetings to descendants”]. Kazan; 1883. 411 p. (In Arabic)

6. Yuzeev A.N. Mardzhani [Marjani]. Kazan: Iman; 1997. 60 p. (In Russian)

7. Safiullina R.R. Arabskaya kniga $v$ dukhovnoy kulture tatarskogo naroda [Arabic book in the spiritual culture of the Tatar people]. Kazan: Alma-Lit; 2003. 214 p. (In Russian)

8. Kemper M. Sufis und Gelehrte in Tatarien und Baschkirien, 1789-1889 [Sufis and scholars in Tatarstan and Bashkortostan, 1789-1889]. Bochum; 1997. 516 p. (In German)

9. Shihab al-Din al-Marjani. Kitab al-hikmat al-baligha al-janiyaya fi sharh al-aqaid al-hanafiyya [Extremely mature wisdom in the interpretation of Hanafi's dogmas]. Kazan: Vecheslav printing house publ.; 1889. 168 p. (In Arabic)

10. Shihab al-Din al-Marjani. Kitab al-hikmat al-baligha al-janiyaya fi sharh al-aqaid al-hanafiyya. Kitab al-fawaid al-muhimma [Extremely mature wisdom in the interpretation of Hanafi's dogmas. Important benefits]. Kazan: Publishing house "Huzur" publ.; 2018. 208 p. (In Arabic)

11. Khayr al-Din al-Zirikli. al-Alam [Famous persons]. Vol. 3. Beirut: Dar al-ilm li-l-Malayin publ.; 1986. 355 p. (In Arabic) 
12. Rudolf U. Al-Maturidi i sunnitskaya teologiya $v$ Samarkande [al-Maturidi and Sunni theology in Samarkand]. Translated from German by 1. Trutanova. Almaty: Foundation of the XXI century publ.; 1999. 286 p. (In Russian)

13. Uludag S. “Aqaid-kelam tarihi, Taftazani ve "Serhull-aqaid” [The history of Islamic dogma, Taftazani and "The interpretation of the creed"]. In: Taftazani. Kelam ilmi ve islam aqaidi (Serhul-aqaid). Edited by Suleyman Uludag. Istanbul: Dergah Yayinlari publ.; 1999, P. 9-87. (In Turkish)

14. Validi Dzh. Ocherk istorii obrazovannosti i literatury tatar do revolucii 1917 g. (fragment knigi) [Essay on the history of education and literature of Tatars before the revolution of 1917 (fragment of the book)]. Biblioteka zhurnala «Kazan» [Library of a "Kazan" magazine]. 1992. №6. 48 p. (In Russian)

15. Khalidov A.B. Al-Mardzhani [al-Marjani]. Islam na territorii bivshey Rossiyskoy imperii [Islam in the former Russian Empire]. In: Enciklopedicheskiy slovar' [Encyclopedic dictionary]. Issue 2. Moscow: "Eastern literature" Russian Academy of Sciences publ.; 1998, P. 60-61. (In Russian)

16. Sihab al-Din al-Marjani. Kitab Wafiyyat al-aslaf wa tahiyyat al-akhlaf [Devotion to predecessors and greetings to descendants]. In: Manuscript in the Department of Manuscripts and Rare books. Kazan Federal University, Vol. 1450, No. 612A. (In Arabic)

17. Abu-n-Nasr Kursavi. Nastavleniye na put istini (al-Irshad li-l-ibad) [Instruction of people on the path of truth]. Kazan:TKI publ.; 2005.304 p. (In Russian)

18. Shigabutdin Mardzhani. Wafiyyat al-aslaf wa tahiyyat al-akhlaf [Devotion to predecessors and greetings to descendants]. Translation from Arabic, commentaries, introductory article and notes by A.N. Yuzeev. Kazan: Iman; 1999. 126 p. (In Russian)

19. Hajji Khalifa (Katib Chelebi). Kashf az-zunun an asami al-kutub wa-lfunun [Disclosure of thoughts regarding book titles and branches of knowledge]. Vol. 2. Baghdad: Maktabat al-Muthanna publ.; 1941, P. 945-2054. (In Arabic)

20. Jalal ad-Dawwani wa hashiyase Khalkhali wa hamishenda hashiyase Marjani [Jalal al-Dawwani's [commentary] and its Khalkhali and Marjani footnotes]. Istanbul: Asad Efendi publ.; 1291 X./1873. 205 p. (In Arabic)

21. Jamal al-Din al-Afghani and Muhammad 'Abduh. Ta'liqat 'ala sharh al'aqaid al-'adhudiyyah [Comments on the commentary of Adhudiyyah creed]. Edited 
by Sayyid Hadi Khosrushahi. Cairo: Maktabat al-Shuruq al-Dawliyyah publ.; 2002. 518 p. (In Arabic)

22. Hashiyat al-mawla al-Marjani [Sheikh al-Marjani footnotes]. Hashiyat al-Shaykh Ismail al-Kalanbawi ala sharh Jalal al-Din al-Dawwani al-Siddiqi [Sheikh Ismail al-Kalanbawi footnotes for Jalal al-Din al-Dawwani al-Siddiqi commentary]. Vol. 1. Istanbul: Dar al-Tibaah al-Amirah publ.; 1317 X. 301 p. (In Arabic)

23. Hashiyat al-mawla al-Marjani [Sheikh al-Marjani footnotes]. In: Hashiyat al-Shaykh Isma'il al-Kalanbawi 'ala sharh Jalal al-Din al-Dawwani al-Siddiqi [Sheikh Ismail al-Kalanbawi footnotes for Jalal al-Din al-Dawwani al-Siddiqi commentary]. Vol. 2. Istanbul: Dar al-Tibaah al-Amirah publ.; 1317 X. 296 p. (In Arabic)

24. Shihab al-Din al-Qazani. Al-Adhb al-furat wa-l-ma al-zulal al-naqi lighullat ruwwam al-ibraz li-asrar sharh al-Jalal [Pleasant, fresh, and life-giving water to quench the intense thirst of those who wish to discover the secrets of Jalal's commentary]. St. Petersburg: State Public Library. F. 907. no. 550. (In Arabic)

25. Shihab ad-Din al-Marjani. al-Barq al-wamidh fi radd ala-l-baghidh almusamma bi-n-naqidh [Brilliant lightning to repel vile attacks]. Kazan: Vecheslav printing house publ.; 1888.133 p. (In Arabic)

26. Muhammad Najib al-Tuntari. Huduth-i aleme itiqad jihatendan ber nazar [View of the issue of the origin of the world from the point of view of Islamic doctrine]. Kazan: University printing house publ.; 1900. 88 p. (In Old Tatar)

27. Shihab al-Din al-Marjani. al-Tariqa al-muthla wa-l-aqida al-husna [Perfect way and the finest belief]. Kazan; 1890.15 p. (In Arabic)

28. Shihab al-Din al-Marjani. al-Tariqa al-muthla wa-l-aqida al-husna [Perfect way and the finest belief]. Department of Rare Books and Manuscripts of a Scientific Library, Kazan Federal University, no. A3049. 5A-24A. (In Arabic)

29. Shihab ad-Din al-Marjani. Aqida mukhtașara [Brief symbol of the Faith]. Majmuat ar-rasail [Collection of treatises]. Cairo: Matbaat Kurdistan al-ilmiyya; 1910, P. 545-552. (In Arabic)

30. Shihab ad-Din al-Marjani. Istina veroucheniya (khakk al-akida) [The truth of the creed (haqq al-aqida)]. In: Preface, translation from Arabic, notes and edition of Arabic text by D.A. Shagaviev. Kazan: Publishing house "Huzur" publ.; 2013. 52 p. (In Russian) [+9 p.] (In Arabic) 


\section{Информация об авторе}

Шагавиев Дамир Адгамович, кандидат исторических наук, доцент кафедры исламской теологии Российского исламского института, старший научный сотрудник Центра исламского наследия Болгарской исламской академии; старший научный сотрудник Центра исламоведческих исследований Академии наук Республики Татарстан.

\section{Раскрытие информации о конфликте интересов}

Автор заявляет об отсутствии конфликта интересов.

\section{Информация о статье}

Поступила в редакцию: 29 октября 2019 Одобрена рецензентами: 20 ноября 2019 Принята к публикации: 23 февраля 2020

\section{About the author}

Damir A. Shagaviev, Cand. Sci. (History), Associate Professor at the Department of Islamic Theology, Russian Islamic Institute, Senior Research Fellow at the Center of Islamic Heritage of Bolgar Islamic Academy, Senior Research Fellow at the Center of Islamic Studies of Tatarstan Academy of Sciences.

\section{Conflicts of Interest Disclosure}

The author declares that there is no conflict of interest.
Article info
Received: October 29, 2019
Reviewed: November 20, 2019
Accepted: February 23, 2020 